The Labore Journal of Economics

11 : 1 (Summer 2006) pp. 63-80

\title{
Determinants of Capital Structure: A Case for the Pakistani Cement Industry
}

\author{
Syed Tahir Hijazi* Yasir Bin Tariq**
}

\begin{abstract}
This paper attempts to determine the capital structure of listed firms in the cement industry of Pakistan. The study finds that a specific industry's capital structure exhibits unique attributes which are usually not apparent in the combined analysis of many sectors as done by Shah \& Hijazi (2005). The study took 16 of 22 firms in the cement sector, listed at the Karachi Stock Exchange for the period 1997-2001 and analyzed the data by using pooled regression in a panel data analysis. Following the model developed by Rajan \& Zingle (1995) it has chosen four independent variables i.e. firm size (measured by natural log of sales), tangibility of assets, profitability and growth and further analyzed the effects on leverage. The results, except for firm size, were found to be highly significant.
\end{abstract}

\section{Introduction}

The firm can choose a mix of financing options to finance its assets so that its overall value can be maximized and this is known as the capital structure of the firm. The seminal work of Miller \& Modigliani (1958) showed that the market value of a firm is determined by its earning power and the risk of its underlying assets, and is independent of the way it chooses to finance its investments or distribute dividends. Remember, a firm can choose between three methods of financing: issuing shares, borrowing or spending profits (as opposed to dispersing them to shareholders as dividends). The theorem gets much more complicated, but the basic idea is that under certain assumptions, it makes no difference whether a firm finances itself with debt or equity.

Although this theory is based on many unrealistic assumptions, it provides the basic theoretical background for further research. After MM a lot of research has been done on optimal capital structure and determinants

\footnotetext{
* Dean, Muhammad Ali Jinnah University, Islamabad.

${ }^{* *} \mathrm{PhD}$ student, Muhammad Ali Jinnah University, Islamabad.
} 
of capital structure. During this period, among others, three main theories emerged which explain the behavior of the firm in choosing its capital structure. These are Static Tradeoff Theory, Pecking Order Theory and the Signaling Theory.

This study focuses on firms of the cement industry of Pakistan and the purpose is two fold. One is to see whether the determinants identified by Rajan \& Zingales (1996) provide an explanation for the choice of capital structure of firms in the Pakistani cement sector. Second, we attempt and to see whether each industry exhibits some unique attributes which are not apparent in the combined analysis of firms from different industries. Therefore, we also compare our results with Shah \& Hijazi (2005) who analyzed 445 non-financial firms listed on the Karachi Stock Exchange representing different industries. We have found that our results differ from Shah \& Hijazi (2005) in terms of growth and size. Also, we have chosen the cement industry because it is a capital-intensive industry and requires a much bigger commitment of funds to setup a new business and to expand its capacity further.

The remainder of this paper is divided into four main sections. Section 2 presents the theoretical basis for the analysis presented in this paper. Section 3 then provides a detailed description of the methodology, operational definitions of the variables and model used. Section 4 then details the results of this analysis, comparing the results with the past findings. Finally, section 5 summarizes and concludes.

\section{Theoretical Framework}

\subsection{Static Trade off Theory}

Myers (1984) divides the contemporary thinking on capital structure into two theoretical currents. The first one is the Static Tradeoff Theory (STT), which explains that a firm follows a target debt-equity ratio and then behaves accordingly. The benefits and costs associated with the debt option sets this target ratio. These include taxes, cost of financial distress and agency cost.

(1) As the interest payments are a tax-deductible expense, they decrease the tax liability thus providing cash savings. Therefore firms will use a higher lever of debt to take the advantage of tax benefits if the tax rates are higher. If the firms incur losses, this tax benefit will fade away. So if the operating earnings are enough to meet the interest expense then firms will get the benefit of tax deductibility of interest expenses. 
The chance of default increases as the level of debt increases. So there exists an optimal level of debt. If the firm goes beyond this optimal point, it is more likely that the firm will default on the repayment of the loan; as a consequence the control of the firm will be shifted from shareholders to bondholders who will try to recover their investments by liquidating the firm. Because of this threat a firm may face two types of bankruptcy costs. These are direct and indirect costs. Direct costs include the administrative costs of the bankruptcy process. If the firm is large in size, these costs constitute only a small percentage for the firm. However, for a small firm, these fixed costs constitute a higher percentage and are considered an active variable in deciding the level of debt. The indirect costs arise because of change in investment policies of the firm in case the firm foresees possible financial distress. To avoid possible bankruptcy, the firm will cut down expenditures on research and development, training and education of employees, advertisements etc. As a result, the customer begins to doubt the firm's ability to maintain the same level of quality in goods and services. This doubt appears in the form of a drop in sales and eventually results in a drop of the market share price of the firm. This implies that the potential benefits from leverage are shadowed by the potential costs of bankruptcy (Correia et al 2000).

\subsection{Pecking Order Theory}

The second theory, the Pecking Order Theory (POT) put forward by Myers (1984) and Myers and Majluf (1984), states that firms follow a hierarchy of financial decisions when establishing its capital structure. Initially, firms prefer to finance their projects through internal financing i.e. retained earnings. In case they need external financing, first they apply for a bank loan then for public debt. As a last resort, the firm will issue equity to finance its project. Thus according to POT the profitable firms are less likely to incur debt for new projects because they have the available internal funds for this purpose. The reason firms are reluctant to issue equity is because of asymmetric information between the management and the new stockholders. Myers and Majluf (1984) pointed out under pricing would be the result of less information held by potential investors vis-à-vis management with respect to the expected cash flows from the firm's assets, both current and future. Considering this information asymmetry investors would infer that the management would issue stock only when it is overpriced. Thus the newly issued equity might be sold at a discount. This would be regarded as a wealth transfer from existing investors to the new 
ones. This problem could be avoided if the firms use internally generated resources, such as retained earnings.

Moreover, the Pecking Order Theory has a more important effect on capital structures for firms that are managed in the interests of equity holders, rather than the combined interests of debt and equity holders. However, when financial distress costs are high, equity-maximizing and value-maximizing firms make similar capital structure choices (Titman \& Tsyplakov 2005).

Myers (1977) suggests that firms acting to maximize the interest of equity holders will be reluctant to issue equity because of the wealth transfer to debt holders, Myers and Majluf (1984) suggest that firms are reluctant to issue equity because of an adverse selection problem, and Almazan, Suarez and Titman (2003) suggest that firms may be reluctant to issue equity because of the costs associated with being scrutinized. Finally, issuing equity involves substantial transaction costs.

These theories are not mutually exclusive. Firms can choose target ratios that reflect the benefits and costs of debt financing put forth in the tradeoff literature, but may deviate from their targets for the reasons described in the pecking order literature.

\subsection{Signaling theory}

This approach, originally developed by Ross (1977), explains that debt is considered as a way to highlight investors' trust in the company, that is if a company issues the debt it provides a signal to the markets that the firm is expecting positive cash flows in the future, as the principal and interest payments on debt are a fixed contractual obligation which a firm has to pay out of its cash flows. Thus the higher level of debt shows the manager's confidence in future cash flows.

Another impact of the signaling factor as we have already discussed it in the Pecking Order Theory is the problem of the underpricing of equity. If a firm issues equity instead of debt for financing its new projects, investors will interpret the signal negatively: since managers have superior information about the firm than investors, they might issue equity when it is overpriced.

Among other explanations about a firm's behavior in choosing its capital structure is the agency theory. Jensen and Meckling (1976) identify the possible conflict between shareholders and a manager's interests because the manager's share is less than $100 \%$ in the firm. Furthermore, acting as an 
agent to shareholders, the manager tries to appropriate wealth from bondholders to shareholders by incurring more debt and investing in risky projects.

This is consistent with the work of Myers (1977) who argues that, due to information asymmetries, companies with high gearing would have a tendency to pass up positive NPV (net present value) investment opportunities (under investment problems). Myers therefore argues that companies with large amounts of investment opportunities (also known as growth options) would tend to have low gearing ratios.

A manager having a less than $100 \%$ stake in the business may try to use these free cash flows sub-optimally or use it to their own advantage rather than use it to increase the value of the firm. Jensen (1986) suggests that this problem can be somehow controlled by increasing the stake of the manager in the business or by increasing debt in the capital structure, thereby reducing the amount of "free" cash available to managers to engage in their own pursuits (Jensen, 1986, Stulz, 1990). Here the reduction in the cash flow because of debt financing is considered to be a benefit.

Stutz (1990) suggests that the agency problem can be solved to some extent if the management stake is increased or the proportion of debt in the capital structure is increased.

\section{Methodology}

This section provides information about the source of data, sample size, measurement of the variables and discussion of different measures of the variables.

\subsection{Source of Data}

This study is based on the financial data of sample firms from 19972001 and has been taken from the State Bank of Pakistan Publications "Balance Sheet Analysis of Joint Stock Companies Listed on the Karachi Stock Exchange Volume-II 1996-2001”. We wished to use the latest data up to 2005, but the data for the period 2002 onward have not yet been published by the State Bank of Pakistan.

\subsection{The Sample}

As this study has focused on the Cement Sector, initially all the 22 firms (which are listed on the Karachi Stock Exchange) in the cement sector 
(whose published data was available) were selected. Then after screening the firms with incomplete data, we were left with only 16 firms. So we have 80 firm-years for panel data analysis.

\subsection{Explanation of Variables:}

In their cross-sectional study of the determinants of capital structure, Rajan and Zingales (1995) examine the extent to which, at the level of the individual firm, leverage may be explained by four key factors, namely, market-to-book (growth), size, profitability and tangibility. Their analysis is performed on a firm-level sample from each of the G-7 countries, and although the results of their regression analysis differ slightly across countries, they appear to uncover some fairly strong conclusions.

This study follows the framework of Rajan \& Zingles (1995) and Shah \& Hijazi (2005) that use tangibility of assets, firm size, growth and profitability of the firm as explanatory variables to determine the degree of leverage (the response variable). In this section we present the description of these variables, how they are measured and what empirical evidence was found by previous studies.

\subsubsection{Leverage (LG) (Dependent Variable)}

Leverage refers to the percentage of assets financed by debt. Previous research studies have used different measures of leverage. Frank and Goyal (2003b) state that the difference between a debt ratio based on market value and one based on book values is that the former tends to regard the firm's future situation whereas the latter reflects the past situation. Fama and French (2002) point out some inconsistencies arising from the use of two different debt ratios. According to them, both theories (Pecking Order and Static Tradeoff) apply to the debt book value, and there are doubts if the predictions may be extended to the debt market value.

Consistent with a previous study on non-financial Pakistani listed firms by Shah \& Hijazi (2005) we used the book value measure of leverage. The main benefit of debt is that the interest payments are tax-deductible and thus provides cash savings. These tax shield benefits are not changed by the market value of the debt once it is issued (Banerjee, S. et. al. 2000). So the market value of the debt is irrelevant for our study.

On the other hand, the primary cost of borrowing is the increased chance of bankruptcy. If a firm falls in financial distress and goes into 
bankruptcy, then the relevant value of the debt is the book value of the debt not the market value of the debt (Shah \& Hijazi 2005).

Another consideration in deciding the appropriate measure of leverage is to take total debt or only long term debt as a percentage of total assets. Though capital structure theories consider long term debt as a proxy for financial leverage, we use the measure of total debt because in Pakistan firms have mostly short-term financing as the average firm size is small. This makes access to the capital market difficult in terms of cost and technical difficulties (Shah \& Hijazi 2005). In Pakistan, firms usually prefer short-term borrowing, the reason being that commercial banks are the major lenders and they do not encourage long-term loans. Up to 1994 firms did not rely on market based debt; in mid 1994 the government amended the Company Law to permit companies to raise debt directly from the market in the form of TFCs (Term Finance Certificates).

Booth et. al. (1999) also pointed out in their study on determinants of capital structure in developing countries including Pakistan that the use of short term financing is greater than long term financing in developing countries.

\subsection{Independent Variables}

\subsubsection{Tangibility of Assets (TG)}

A firm having a large amount of fixed assets can easily raise debt at cheaper rates because of the collateral value of those fixed assets. The companies with a higher ratio of tangible assets have an incentive to borrow more because loans are available to them at a relatively cheaper rate. Therefore we expect a positive relationship between tangibility of assets and leverage.

According to the static tradeoff approach, firms with higher ratio of fixed assets serve as collateral for new loans, favoring debt. However, the Pecking Order Theory is of the view, as argued by Harris and Raviv (1991), that firms with low levels of fixed assets would have more problems of asymmetric information, making them issue more debt, since equity issues would only be possible by under pricing them. On the other hand, firms with higher levels of asset tangibility are generally larger firms, that can issue equity at fair prices, so they do not need to issue debt to finance new investment. According to them, the expected relationship between asset tangibility and debt should then be negative. 
Tangibility of assets is measured in this study as the ratio of fixed assets to total assets. We take the total gross amount of fixed assets as the numerator. Using total gross fixed assets rather than net depreciated value of assets makes sense as (i) different firms may possibly use different depreciation methods that may create unevenness in the data (ii) a firm can pledge an asset having a market value even if it has been fully depreciated. Calculating tangibility this way, the ratio was above one in some cases suggesting that total gross fixed assets were more than total assets (Shah \& Hijazi 2005).

Therefore our first hypothesis is that a firm with higher percentage of fixed assets will have higher debt ratio.

\subsubsection{Size (SZ)}

For the Static Tradeoff approach, the larger the firm, the greater the possibility it has of issuing debt, resulting in a positive relationship between debt and size. One of the reasons for this is that the larger the firm the lower is the risk of bankruptcy. Large firms do not consider the direct bankruptcy costs as an active variable in deciding the level of leverage as these costs are fixed by the Constitution and constitute a smaller proportion of the total firm's value and also because larger firms, being more diversified, have less chances of bankruptcy (Titman and Wessels 1988).

With respect to the Pecking Order Theory, Frank and Goyal (2003a), and Rajan and Zingales (1995) argued that this relationship could be negative. There is less asymmetrical information about the larger firms, reducing the chances of undervaluation of the new equity issue, encouraging large firms to use equity financing. This means that there is a negative relationship between size and leverage of the firm. Following Rajan and Zingales (1995), we expect a negative relationship between size and leverage of the firm. The natural log of sales is generally used to proxy firm size. The use of the $\log$ of sales instead of sales is justified by the non-linearity between sales and size from some point onwards. For Titman and Wessels (1989), the rationale for this is that if there is a size effect to debt, it will be higher for small firms.

We measure size (SZ) of the firm by the taking the natural log of the sales as this measure smoothens the variation over the periods considered. 
Therefore our second hypothesis is that there is a negative relationship between size and leverage of the firm i.e. the bigger the firm, the lower will be the leverage level.

\subsubsection{Growths $(G T)$}

For growth, different measures have been used in the past. The market-to-book ratio is used by Rajan and Zingales as a proxy for the level of growth opportunities available to the enterprise. This is in common with most studies, which tend to apply proxies, rather than valuation models to estimate growth opportunities (Danbolt et. al. (1999)). Rajan and Zingales suggest that one would expect a negative relation between growth opportunities and the level of gearing. This is consistent with the theoretical predictions of Jensen and Mekling (1976) based on agency theory, and the work of Myers (1977), who argues that, due to information asymmetries, companies with high gearing would have a tendency to pass up positive NPV (net present value) investment opportunities. Myers therefore argues that companies with large amounts of investment opportunities (also known as growth options) would tend to have low gearing ratios.

Moreover, as growth opportunities do not yet provide revenue, companies may be reluctant to take on large amounts of contractual liabilities at this stage. Similarly, as growth opportunities are largely intangible, they may provide limited collateral value or liquidation value (in a similar spirit to the discussion of tangibility below). Companies with growth options may thus not wish to incur - nor necessarily be offered additional debt financing (Bevan \& Danbolt 2000).

However, the empirical evidence regarding the relationship between gearing and growth opportunities is rather mixed. Titman and Wessels (1988), Chung (1993) and Barclay et. al. (1995) Rajan and Zingales (1995) and Shah and Hijazi (2005) find a negative correlation, whereas Kester (1986) does not find any support for the predicted negative relationship between growth opportunities and gearing. This is therefore consistent with the hypotheses of Jensen and Mekling (1976) and Myers (1977), and lends weight to the notion that companies with high levels of growth opportunities can be expected to have low levels of gearing.

For the POT, there are two possibilities for the sign of this variable: one the one hand, firms with high growth opportunities would tend to keep their debt ratios at low levels so as to preserve their credit capacity when it becomes necessary (negative impact), and on the other hand, this growth requires investments which are usually made with the 
issue of new debt (positive impact). Fama and French (2002) named these two possibilities as the complex and simple versions of the POT, respectively.

Different research studies have used different measures of growth; like market to book value of equity, research expenditure to total sales measure and annual percentage increase in total assets (Titman and Wessels, 1988). Given the structure of data we measure growth (GT) as a percentage increase in total assets, as the data was taken from the State Bank of Pakistan publication which does not have information on annual stock prices an research expenditure of the listed firms (Shah and Hijazi 2005).

Thus we expect a positive coefficient for growth. Our third hypothesis is that firms with higher growth rate will have higher leverage.

\subsubsection{Profitability (PF)}

Profitability is a strong point of dissent between the two theories i.e. Pecking Order Theory (POT) and Static Tradeoff Theory (STT). For the STT, the higher the profitability of the firm, the more reasons it will have to issue debt, reducing its tax burden. On the other hand, the POT presupposes that larger earnings lead to the increase of the main source firms choose to cover their financial deficit: retained earnings. Therefore, the STT expects a positive relationship between profitability and leverage, whereas the POT expects exactly the opposite.

In previous studies, the measure of profitability used was operating earnings before interest payments and income tax (EBIT). But following Shah and Hijazi (2005) we measure profitability (PF) as the ratio of net income before taxes divided by total assets because the data taken from the State Bank of Pakistan publication does not permit us to calculate EBIT.

Thus our fourth hypothesis is that firms with higher profitability will have less leverage.

Thus our four hypotheses that we will test are:

Hypothesis 1: A firm with a higher percentage of fixed assets will have a higher debt ratio (positive relationship). 
Hypothesis 2: There negative relationship between size and leverage of the firm i.e. the bigger the firm; the lower will be the leverage level.

Hypothesis 3: Firms with a higher growth rate will have higher leverage (positive relationship).

Hypothesis 4: Firms with higher profitability will have less leverage (negative relationship).

\subsection{The Regression Model}

This study uses panel regression analysis. Panel data analysis facilitates analysis of cross-sectional and time series data. We use the pooled regression type of panel data analysis. The pooled regression, also called the Constant Coefficients mode1, is one where both intercepts and slopes are assumed constant. The cross section company data and time series data are pooled together in a single column assuming that there is no significant cross section or inter temporal effects.

Therefore the equation for our regression model will be:

$$
\mathrm{LG}=\beta_{0}+\beta_{1}(\mathrm{TG})+\beta_{2}(\mathrm{SZ})+\beta_{3}(\mathrm{GT})+\beta_{4}(\mathrm{PF})+\varepsilon
$$

Where

$$
\begin{aligned}
& \text { LG }=\text { Leverage } \\
& \text { TG }=\text { Tangibility of assets } \\
& \text { SZ }=\text { Firm Size measure by Log of sales } \\
& \text { GT }=\text { Growth } \\
& \text { PF }=\text { Profitability } \\
& \varepsilon=\text { the error term }
\end{aligned}
$$

\section{Analysis \& Results}

This sections contains the results of the descriptive and regression analysis. Table 1 shows the summary of descriptive statistics for the variable values in the sample. 
Table-1: Descriptive Statistics (5-year summary)

\begin{tabular}{lccccc}
\hline & N & Minimum & Maximum & Mean & Std. Deviation \\
\hline Leverage & 80 & 0.18 & $2.51^{1}$ & 0.7079 & 0.47634 \\
Size & 80 & 2.53 & 8.43 & 6.9520 & 1.35107 \\
Profitability & 80 & -0.45 & 0.28 & -0.0582 & 0.11573 \\
Tangibility & 80 & 0.70 & $2.84^{2}$ & $1.2580^{1}$ & 0.42007 \\
Growth & 80 & -0.32 & 0.40 & -0.0172 & 0.09998 \\
\hline
\end{tabular}

To check for the presence of multicollinearity among predictor variables we check the Spearman's Correlation among them which is given in table 2 below.

Table-2: Spearman's Correlation Coefficient between predictor variables (A check for multicollinearity)

\begin{tabular}{llccc}
\hline & Size & Profitability & Tangibility & Growth \\
\hline Size & 1 & 0.058 & 0.176 & -0.037 \\
Profitability & 0.058 & 1 & -0.529 & 0.393 \\
Tangibility & 0.176 & -0.529 & 1 & -0.548 \\
Growth & -0.036 & 0.393 & -0.548 & 1 \\
\hline
\end{tabular}

From Table-2 it can be seen that the highest correlation value between two variables is -0.548 which shows that a multicollinearity problem is not present among the selected independent variables.

From Table-2 we can see that tangibility is negatively correlated with profitability and growth, and positively correlated with the size of the firm. The negative correlation between growth and firm size shows that in the

\footnotetext{
${ }^{1}$ Theoretically, total debt/total assets ratio should be less than one or one at maximum. However, we find many firms have negative equity that explains why this ratio is greater than one.

${ }^{2}$ Theoretically speaking, fixed assets/total assets too should be lower than one. However, we use gross fixed assets/ total assets ratio as a measure of tangibility. Tangibility ratio of above one indicates that the firm has a sufficient number of depreciated yet indisposed-of assets so that the gross value of all these assets is fairly higher than the total present depreciated value of all assets (Shah and Hijazi, 2005).

${ }^{3}$ A mean value of higher than one shows that in the cement industry the average firm has a sufficient number of depreciated but not disposed off assets.
} 
cement sector the increase in assets is negligible. There, growth happened marginally i.e. by installing new plants for increasing production. Unless a new plant is installed the growth in terms of assets remains stagnant. On the other hand by increasing capacity utilization production and sales increase and the asset's value decreases due to depreciation. That is why we found a negative correlation between growth and size.

\subsection{Regression Analysis Results}

The following tables present the results of pooled regression analysis.

Table-3.1: Regression Model Summary

\begin{tabular}{cccc}
\hline $\mathbf{R}$ & R Square & Adjusted R Square & Std. Error of the Estimate \\
\hline 0.860 & 0.739 & 0.725 & .24988 \\
\hline
\end{tabular}

Table-3.2: ANOVA (b)

\begin{tabular}{lrrrrr}
\hline & $\begin{array}{c}\text { Sum of } \\
\text { Squares }\end{array}$ & DF & $\begin{array}{c}\text { Mean } \\
\text { Square }\end{array}$ & F & Sig. \\
\hline Regression & 13.242 & 4 & 3.310 & 53.018 & $.000(\mathrm{a})$ \\
Residual & 4.683 & 75 & 0.062 & & \\
Total & 17.925 & 79 & & & \\
\hline
\end{tabular}

a -Predictors: (Constant), Growth, Size, Profitability, Tangibility

b- Dependent Variable: Leverage

Table-3.3: Regression Coefficients \& their significance

\begin{tabular}{lccccc}
\hline & \multicolumn{2}{c}{$\begin{array}{c}\text { Un-standardized } \\
\text { Coefficients }\end{array}$} & $\begin{array}{c}\text { Standardized } \\
\text { Coefficients }\end{array}$ & t-statistic & \multirow{2}{*}{ Sig. } \\
\cline { 2 - 4 } & Beta & $\begin{array}{c}\text { Std. } \\
\text { Error }\end{array}$ & Beta & & \\
\hline (Constant) & -0.093 & 0.164 & & -0.564 & 0.574 \\
Size & -0.014 & 0.022 & -0.039 & -0.641 & 0.524 \\
Profitability & -2.345 & 0.294 & -0.570 & -7.979 & 0.000 \\
Tangibility & 0.622 & 0.090 & 0.549 & 6.888 & 0.000 \\
Growth & 1.340 & 0.340 & 0.281 & 3.940 & 0.000 \\
\hline
\end{tabular}


The above tables show the results of the regression analysis. The value of $R$-square $\left(R^{2}=0.739\right.$ : Table 3.1$)$ shows that the four variables i.e. growth, size, profitability and tangibility explain nearly $74 \%$ of variation in the response variable leverage. This means that the choice of capital structure is mainly defined by these four variables in the cement sector. The Adjusted R-square is slightly below the $\mathrm{R}^{2}$. From the value of the F-statistic we can see that the model is significant at the $1 \%$ level of significance.

\section{Table-4 Expected \& Observed Relationships}

\begin{tabular}{llcc}
\hline Determinant & \multicolumn{1}{c}{ Measure (proxy) } & $\begin{array}{c}\text { Expected } \\
\text { relationship } \\
\text { with leverage }\end{array}$ & $\begin{array}{c}\text { Observed } \\
\text { relationship }\end{array}$ \\
\hline Size & Log of Sales & Negative & Negative $^{1}$ \\
Profitability & EBT/Total Assets & Negative & Negative $^{\text {Tangibility }}$ \\
& $\begin{array}{l}\text { Total Gross Fixed } \\
\text { Assets/Total Assets }\end{array}$ & Positive & Positive \\
& Annual Percentage & Positive & Positive \\
& Change in Total Assets. & & \\
\hline
\end{tabular}

${ }^{1}$-The relationship is statistically insignificant.

From Table-4 we see that all the variables exhibit the same relationship as expected at the $1 \%$ level of significance. Other than size (log of sales) all the coefficients are statistically significant at the $1 \%$ level of significance.

The size of the firms is negatively correlated with leverage $\left(\beta_{1}=-0.14\right.$; Table 3.3). However the regression coefficient is not statistically significant. Although the sign of the coefficient confirms the direction of our relationship of size with the degree of indebtedness i.e. leverage, the statistical significance does not support our hypothesis. Therefore we reject our first hypothesis.

The results are not consistent with the Rajan and Zingales (1995) view of less asymmetric information about large firms suggesting that new equity issues will not be underpriced and thus large firms will issue more equity. Also Shah and Hijazi (2005) found a positive relationship between size and leverage therefore suggesting that in Pakistan on average larger firms prefer to incur more debt. 
Profitability is negatively correlated with leverage $\left(\beta_{2}=-2.345\right.$; Table 3.3). This suggests that profitable firms in the Pakistani cement sector use more equity and less debt. Thus the conclusion might be that higher profitability keeps firms away from debt instead of encouraging it, exactly as foreseen by the POT. Therefore we will accept our second hypothesis at the $1 \%$ level of significance. The same results were observed by Shah and Hijazi (2005).

Asset tangibility is positively correlated with leverage $\left(\beta_{3}=0.622\right.$; Table 3.3). The results thus favor the Meckling's (1976) and Myers' (1977) version of the trade-off theory that debt level should increase with more fixed tangible assets on the balance sheet. Therefore we will accept our third hypothesis at the $1 \%$ level of significance.

Finally growth was found to be positively correlated with leverage $\left(\beta_{4}=1.340\right.$; Table 3.3). This suggests that growing firms in the Pakistani cement industry use more debt than equity to finance the new projects. One possible reason for this is: in order to grow in the cement sector huge cash flows are needed, which a growing firm may not be able to meet through internal sources only and therefore they have to rely on debt. This confirms our earlier hypothesis about growth opportunities. On the other hand Shah and Hijazi (2005) found a negative relationship between growth and leverage.

Our results do not support the simple version of the Pecking Order Theory that suggests growing firms will resort first to internally generated funds to fulfill their financing needs. But it supports the extended version of the Pecking Order Theory that suggests that internally generated funds may not be sufficient for growing firms and the next option for such a firm would be to use debt financing. The results are statistically significant at the $1 \%$ level of significance.

\section{Conclusion:}

In this study we analyzed a sample of 16 firms in the cement sector by using a pooled regression model to measure the determinants of capital structure of the firms in the cement industry.

The results were found to be as expected. Also, we find an inverse relationship between size and growth. This shows firms in the cement sector show different behavior than was found to be the case in previous studies. Firm size is negatively correlated with leverage thus suggesting that the bigger the firm size the less debt they will use. Thus the results reject the 
Static Tradeoff Theory, which expects a positive relationship between firm size and leverage.

Table-5: Comparisons with Static Tradeoff Theory \& Pecking Order Theory

\begin{tabular}{lllcc}
\hline Determinant & Measure(proxy) & $\begin{array}{c}\text { Observed } \\
\text { relationship }\end{array}$ & $\begin{array}{c}\text { Expected } \\
\text { relationship } \\
\text { in STT }\end{array}$ & $\begin{array}{c}\text { Expected } \\
\text { relationship } \\
\text { in POT }\end{array}$ \\
\hline Size & Log of Sale & Negative & Positive & Positive \\
Profitability & EBT/Total Assets & Negative & Positive & Negative \\
Tangibility & Total Gross Fixed & Positive & Positive & Negative \\
& Assets/Total Assets & & & \\
Growth & Annual Percentage & Positive & Negative & Negative \\
& Change in Total & & & \\
& Assets. & & & \\
\hline
\end{tabular}

Profitability and leverage were found to be negatively correlated. Thus the results support the Pecking Order Approach and reject the Static Tradeoff approach.

The results show also that assets tangibility is positively correlated with debt. This is consistent with the previous empirical studies by Titman and Wessels (1988), Rajan and Zingales (1995) and Fama and French (2000), which say that tangibility should be an important determinant of leverage.

Growth measured by the annual percentage change in total assets is positively correlated with leverage supporting the extended version of the Pecking Order Theory that suggests that internally generated funds may not be sufficient for growing firms and the next option for such firms would be to use debt financing. 


\section{References}

"Balance Sheet Analysis of Joint Stock Companies Listed on The Karachi Stock Exchange Volume II” (2001), State Bank of Bank of Pakistan.

Bevan, A. and Danbolt, J., 2000, "Capital Structure \& its Determinants in the United Kingdom: A Decompositional Analysis” SSRN Working Paper Series, http://papers.ssrn.com/so13/papers.cfm?abstract_id = 233550 (Published by the Department of Accounting \& Finance, University of Glasgow. ISBN 0852616325 ).

Booth, L., V. Aivazian, A. Demirguc-Kunt and V. Maksmivoc, 2001, Capital structures in developing countries, Journal of Finance 56, 87-130.

Fama, E., 1980, “Agency Problems and Theory of the Firm”, Journal of Political Economy, Vol. 88, No. 2.

Frank, M.Z. and Goyal, V.K., 2003a, "Testing the pecking order theory of capital structure". Journal of Financial Economics, Vo1. 67.

Harris, M. and A. Raviv, 1990, Capital structure and the informational role of debt, Journal of Finance 45, 321-349.

Modigliani, F. and Miller, M.H., 1958, "The Cost of Capital, Corporation Finance and the Theory of Investment", The American Economic Review, Vol. 48, No. 3.

Modigliani, F. and Miller, M.H., 1963, "Corporate Income Taxes and the Cost of Capital: A Correction”, The American Economic Review, Vol. 48, No. 3.

Myers, S., and N. Majluf, 1984, Corporate Financing and Investment Decisions When Firms Have Information Investors Do Not Have, Journal of Financial Economics 13, 187-222.

Myers, S.C., 1977, "Determinants of Corporate Borrowing”, Journal of Financial Economics, Vo1. 5.

Rajan, R. and Zingales, L., 1995, "What Do We Know about Capital Structure? Some Evidence from International Data”, Journal of Finance, Vo1. 50. 
Ross, S.A., 1977, "The determination of financial structure: the incentive signaling approach", Bell Journal of Economics 23-40.

Scott, J.H., 1977, "Bankruptcy, Secured Debt and Optimal Capital Structure”, Journal of Finance, Vol. 32.

Shah, Atta, and Hijazi S., 2005, "The Determinants of Capital Structure in Pakistani Listed Non-Financial Firms”, presented at $20^{\text {th }}$ AGM \& Conference of Pak Society of Development Economics (Jan. 11, $2005)$.

Stultz, R., 1990, "Managerial Discretion and Optimal Financing Policies", Journal of Financial Economics, Vo1. 26.

Titman, S. and Tsyplakov, S., 2005, “A Dynamic Model Capital Structure” SSRN Working Paper Series http://papers.ssrn.com/sol3/papers.cfm? abstract_id=332042.

Titman, S. and Wessels, R., 1988, “The Determinants of Capital Structure Choice", Journal of Finance, Vol. 43. 